THE FISHES AND THE FOREST 



\section{THE FISHES AND THE FOREST}

Explorations in Amazonian Natural History

Michael Goulding

University of California Press

Berkeley Los Angeles London 


\section{University of California Press}

Berkeley and Los Angeles, California

University of California Press, Ltd.

London, England

Copyright (c) 1980 by the Regents of the University of California

Library of Congress Cataloging in Publication Data

\section{Goulding, Michael.}

The fishes and the forest, explorations in Amazonian natural history.

Bibliography Includes index

1. Fishes-Brazil-Madeira River watershed-Ecology. 2. Fishes-Amazon River watershed-Ecology. 3. Rain torest ecology-Brazil-Madeira River watershed. 4. Rain torest ecology-Amazon River watershed. 5. FishesEcology. 1. Title.

QL632.B8G68 $597^{\prime} .05^{\prime} 09811$

$80-51201$

ISBN O-520-04131-3

Printed in the United States of America
$\begin{array}{lllllllll}1 & 2 & 3 & 4 & 5 & 6 & 7 & 8 & 9\end{array}$ 